\title{
ANALISIS KANDUNGAN KARBOHIDRAT PADA PLANLET BUNCIS (Phaseolus vulgaris L.) SECARA IN VITRO HASIL INDUKSI KALIUM DALAM CEKAMAN KEKERINGAN
}

\author{
Endang Nurcahyani ${ }^{1}$, Dian Alfiah ${ }^{2}$, Sri Wahyuningsih ${ }^{2}$, Mahfut ${ }^{1}$ \\ ${ }^{1}$ Program Studi Biologi Terapan, Jurusan Biologi, FMIPA, Universitas Lampung \\ ${ }^{2}$ Program Studi Biologi, Jurusan Biologi, FMIPA, Universitas Lampung \\ endang.nurcahyani@fmipa.unila.ac.id
}

Artikel Info
Diterima
tanggal
12.09 .2019
Disetujui
publikasi
tanggal
30.04 .2020
Kata kunci : in
vitro,Kalium,
Karbohidrat,
Phaseolus
vulgaris L.
Poly Ethylen
Glycol

\begin{abstract}
ABSTRAK
Buncis (Phaseolus vulgaris L.) merupakan tanaman semusim berbentuk perdu. Pada tahun 2017 produktivitas buncis mengalami penurunan karena minimnya lahan produksi. Kendala yang dihadapi dalam memproduksi buncis antara lain musim kemarau yang berkepanjangan. Kalium dapat membantu penyerapan unsur hara dan air pada tumbuhan. Poly Ethylene Glycol (PEG 6000) diberikan pada medium kultur jaringan untuk menstimulasi cekaman kekeringan. Penelitian ini menggunakan medium Murashige and Skoog (MS) dengan pemberian kalium. Penelitian ini bertujuan untuk mengetahui efek pemberian kalium pada planlet buncis yang tahan serta untuk mengetahui kandungan karbohidrat pada planlet buncis secara in vitro. Penelitian ini menggunakan Rancangan Acak Lengkap (RAL) dengan satu faktor yaitu konsentrasi kalium dengan 4 taraf perlakuan: $0 \%, 0,5 \%$, $0,15 \%$, dan 0,25\% dengan 6 ulangan. Data dianalisis dengan menggunakan ANOVA pada taraf $5 \%$. Hasil penelitian menunjukkan bahwa persentase planlet hidup menunjukkan 100\% hidup dan pemberian kalium dan PEG 6000 belum memberikan pengaruh terhadap kadar karbohidrat terlarut total secara in vitro.
\end{abstract}

\section{ABSTRACT}

Beans (Phaseolus vulgaris L.) is a shrub shaped annual plants and included in the group of nuts that are popular with the community. In 2017 bean productivity decreased due to lack of production land. The obstacles faced in producing beans include a prolonged dry season. Potassium can help the absorption of nutrients and water in plants. Poly Ethylene Glycol (PEG 6000) applied to tissue culture medium to stimulate drought stress. This research uses medium Murashige and Skoog (MS) by giving potassium. This study to purpose determine the effect of potassium to green beans resistant and knows the total dissolved carbohydrate content in vitro. This study uses a Completely Randomized Design with variations in the concentration of Indole Acetic Acid which consists of 4 levels of treatment namely 0\%, 0.5\%, 0.15\%, and 0.25\%. Each concentration was repeated 6 times and each repetition consisted of 3 explants of bean seeds in each culture bottle. Data were analyzed using the Homogeneity Test at the 5\% significance level. The results showed that the percentage of live plantlets showed 100\% life and the provision of potassium and Poly Ethylene Glycol (PEG 6000) hasn affected the totaldissolved carbohydrate levels in vitro.

doi: http://dx.doi.org/10.23960/aec.v5.i1.2020.p34-41

Anal.Environ.Chem. 


\section{PENDAHULUAN}

Buncis (Phaseolus vulgris L.) merupakan tanaman semusim berbentuk perdu. Peningkatan produksi buncis memiliki arti penting dalam menunjang gizi masyarakat, sekaliguss berdaya guna bagi usaha mempertahankan kesuburan dan produktivitas tanah. Buncis merupakan salah satu sumber protein yang murah dan mudah dikembangkan (Saparinto, 2013). Badan Pusat Statistik (2017) menyatakan bahwa pada tahun 2017 produktivitas buncis mencapai 318.214 ton/tahun. Tahun 2018 produktivitas buncis buncis mengalami penurunan menjadi 291.314 ton/tahun. Penurunan produksi buncis ini dikarenakan sedikitnya lahan produksi buncis dan pengembanagn industri benih buncis masih minim, dengan demikian kondisi tersebut mengakibatkan harga buncis menjadi melambung dan mendorong petani untuk meningkatakan produktivitas buncis.

Solusi untuk mengatasi permasalahan lahan kering yaitu menggunakan unsur kalium. Kalium sangat berperan dalam menekan proses penguapan sehingga dapat meningkatkan ketahanan tanaman terhadap kekeringan dan tahan terhadap penyakit (Suriatana, 1987). Menurut Fauzy et al. (2016), tanaman dapat dikembangbiakkan secara generatif dan vegetatif. Salah satu teknik pembiakan tanaman vegetatif yaitu dengan teknik kultur jaringan tanaman. Keberhasilan kultur jaringan ditentukan oleh medium kultur jaringan yang merupakan tempat tumbuh bagi eksplan. Salah satunya medium dasar Murashige and skoog (MS) yang paling banyak digunakan dalam kultur jaringan.

Poly Ethylene Glycol (PEG) dapat menstimulasi cekaman kekeringan karena sifatnya dapat menyerap air. Penggunaan PEG 6000 dalam medium in vitro diharapkan dapat menciptakan potensi osmotic yang setara dengan kondisi lapangan kelembapan tanah dan titik kritis pada air sehingga eksplan memberikan respon yang sama dengan respon tanaman yang mengalami cekaman kekeringan (Mariska dan Lestari, 2006). Cekaman kekeringan merupakan kondisi dimana keterbatasan kadar air dalam tanah berpengaruh terhadap pertumbuhan dan produksi suatu tanaman. Selain itu, cekaman kekeringan dapat menyebabkan rendahnya laju fotosintesis, penutupan stomata, penurunan pertumbuhan daun serta perubahan indeks luas daun serta menghambat fotosintesis (Kurniasari et al., 2010).

Pada saat cekaman kekeringan, tanaman akan mengurangi penggunaan karbohidrat untuk mempertahankan proses metabolismenya, dan hal ini memicu berkurangnya karbon

doi: http://dx.doi.org/10.23960/aec.v5.i1.2020.p34-41

Anal.Environ.Chem. 
sehingga tanaman akan mengalami penurunan dan akan mengalami kematian (Liu et al., 2007). Kandungan karbohidrat terlarut total merupakan parameter yang tepat untuk digunakan dalam cekaman kekeringan. Kandungan karbohidrat berperan dalam mengatur tekanan potensial air pada cekaman kekeringan dan dapat diamati dari batang yang merupakan organ tanaman yang banyak mengandung konsentrasi gula dan menunjukkan karakterisasi perubahan genotip pada kondisi tercekam (Kerepesi dan Galiba, 2000). Penelitian mengenai kandungan karbohidrat terlarut total pernah dilakukan pada Buncis (Nurcahyani dkk., 2019a), kacang panjang (Nurcahyani, 2019b) yang tercekam kekeringan secara in vitro.Pada penelitian ini disajikan mengenai kandungan karbohidrat pada Buncis hasil induksi kalium dalam keadaan cekaman kekeringan secara in vitro.

\section{METODE}

\section{Alat dan Bahan}

Alat-alat yang digunakan dalam penelitian ini adalah Laminar Air Flow (LAF) Cabinet merk Esco sebagai meja steril yang dilengkapi dengan blower dan lampu UV untuk penanaman eksplan atau subkultur tunas pada medium dalam botol, autoclave digunakan sebagai sterilisasi basah, plastic wrap, scalpel, magnetic stirrer, hot plate atau kompor, alumunium foil, label, bunsen, beaker glass, gelas ukur, batang pengaduk, botol kultur, pipet tetes, cawan petri, pinset, gunting, neraca analitik, $\mathrm{pH}$ meter, kertas Whatman No 1, spektrofotometer, mortar, karet gelang, mistar, lemari kultur, tissue, tabung gas, panci, korek api, kamera hp, masker dan sarung tangan. Bahan-bahan yang digunakan adalah eksplan buncis (Phaseolus vulgaris L.) medium Murashige and Skoog (MS) "use ready" diproduksi oleh Caisson Laboratories, agar-agar 7g/L, gula 30g/L, KOH $1 \mathrm{~N}, \mathrm{HCL} 1 \mathrm{~N}$, PPM 0,5 ml/L, kalium dengan konsentrasi 0\%, 0,5\%, 0,15\%, dan 0,25\%, alkohol 70\% dan 96\%, aquades dan spiritus dan PEG 6000 (Poly Ethylene Glycol) $\mathrm{H}_{2} \mathrm{SO}_{4}$ dan Fenol sebanyak $2 \mathrm{ml}$.

\section{Prosedur}

Medium tanam dibuat sebanyak 1 L. Pembuatan medium Murashige and Skoog (MS) dilakukan dengan cara medium MS “use ready" ditimbang sebanyak 4,43 g/L, lalu dicampurkan

doi: http://dx.doi.org/10.23960/aec.v5.i1.2020.p34-41

Anal.Environ.Chem. 
dengan gula $30 \mathrm{~g} / \mathrm{L}$, kemudian dilarutkan menggunakan aquades secukupnya ke dalam beaker glass dengan menggunakan magnetic stirrer dan diletakkan di atas hotplate. Medium MS yang sudah dilarutkan dimasukkan ke dalam gelas ukur, kemudian ditambah aquades mencapai volume $1000 \mathrm{ml}$. Larutan medium dimasukkan ke dalam panci dan diukur $\mathrm{pH}$-nya hingga mencapai 5,7 dalam kondisi netral (apabila medium terlalu asam maka ditambahkan $\mathrm{KOH} 1 \mathrm{~N}$ dan apabila medium terlalu basa maka ditambahkan HCL 1 N). Agar sebanyak 7 gr/L dan PPM 0,5 ml/L dimasukkan ke dalam panci, lalu dimasak dan diaduk hingga mendidih. Selanjutnya, medium tersebut dituangkan ke dalam botol masing-masing sebanyak $20 \mathrm{ml} /$ botol kultur. Konsentrasi 0\% (kontrol) tidak diberi perlakuan, tetapi perlakuan ditetesi air kelapa (5\%, 10\%, dan 15\%) sebanyak 20 tetes ke dalam masing-masing botol kultur, tutup menggunakan alumunium foil, dan diberi label menggunakan pensil pada masing-masing perlakuan.

Penanaman eksplan dilakukan di dalam LAF Cabinet. Langkah pertama biji kacang kedelai direndam dalam bayclean selama 5 menit lalu dibilas dengan air mengalir sebanyak 3 kali. Setelah itu direndam dalam larutan bayclin 20\% selama 2-3 menit. Biji kacang kedelai dibilas dengan aquades, pembilasan dilakukan sebanyak dua kali. Setelah itu dipindahkan ke dalam cawan petri selanjutnya benih ditanam pada medium seleksi dengan penambahan air kelapa. Setiap botol kultur ditanami 2 biji, sehingga total biji yang ditanam sebanyak 48 dalam 24 botol kultur. Biji-biji kacang kedelai tersebut di tumbuhkan hingga menjadi planlet pada medium MS.

Analisis kandungan karbohidrat menggunakan batang planlet buncis yang sudah diberikan perlakuan kombinasi medium MS dengan PEG 6000, menggunakan metode fenolsulfur Witham et al.,(1993) dengan spektrofotometer yang dilakukan pada akhir pengamatan. Batang planlet sebanyak 0,1 g, digerus dengan mortar, ditambahkan $10 \mathrm{~mL}$ aquades lalu di sentrifus selama 30 menit. Kemudiaan filtrat diambil sebanyak $1 \mathrm{ml}$ dan ditambah $1 \mathrm{ml} \mathrm{H}_{2} \mathrm{SO}_{4}$ kemudianditambah fenol sebanyak $2 \mathrm{ml}$, kemudian larutan disaring dengan kertas Whatman No.1 dan dimasukkan ke dalam flakon lalu ditutup rapat. Larutan sampel dan larutan standar diambil sebanyak $1 \mathrm{~mL}$ dimasukkan dalam kuvet. Setelah itu dilakukan pembacaan serapan dengan spektrofotometer UV pada panjang gelombang $490 \mathrm{~nm}$, dengan tiga kali ulangan sampel.

doi: http://dx.doi.org/10.23960/aec.v5.i1.2020.p34-41

Anal.Environ.Chem. 


\section{HASIL DAN PEMBAHASAN}

\section{A. Persentase Jumlah planlet yang hidup}

Planlet yang steril dihitung sebagai eksplan yang mampu merespon kalium dan PEG 6000 hingga 3 MST dan selama masa perlakuan dilakukan pengamatan pertumbuhan dalam medium tanam yang memiliki ciri morfologi yang seragam (Tabel 1).

Tabel 1. Persentase jumlah planlet buncis yang hidup setelah di induksi kalium dan PEG 6000 per konsentrasi pada pengamatan minggu ke-3 kultur in vitro.

\begin{tabular}{ccccc}
\hline $\begin{array}{c}\text { PEG 6000 } \\
\text { Konsentrasi }\end{array}$ & Konsentrasi Kalium (\%) & \multicolumn{3}{c}{ Persentase Jumlah Planlet } \\
$(\%)$ & & Hidup pada Minggu (\%) \\
& & I & II & III \\
\hline & 0 & 100 & 100 & 100 \\
20 & 0,5 & 100 & 100 & 100 \\
& 0,15 & 100 & 100 & 100 \\
\hline
\end{tabular}

Keterangan: Angka 100\% menandakan bahwa planlet hidup dari minggu ke-1 sampai minggu ke-3.

Berdasarkan Tabel 1, dapat diketahui bahwa perlakuan dengan penambahan kalium pada berbagai konsentrasi yaitu $0 \%, 0,5 \%, 0,10 \%$, dan $0,25 \%$ terhadap planlet buncis pada minggu ke-I sampai minggu ke-III didapatkan $100 \%$ planlet hidup dan tidak ada yang mati. Planlet yang hidup ditunjukkan dengan bertambahnya tinggi planlet, bertambahnya daun, dan munculnya tunas pada planlet. Jumlah sampel per perlakuan yang dicobakan sebanyak 3 sampel buncis pada setiap botol kultur. Selanjutnya eksplan buncis ditanam pada medium perlakuan, kemudian diamati hingga eksplan berumur 3 minggu setelah perlakuan. Pertumbuhan planlet disajikan pada

\section{Gambar 1.}
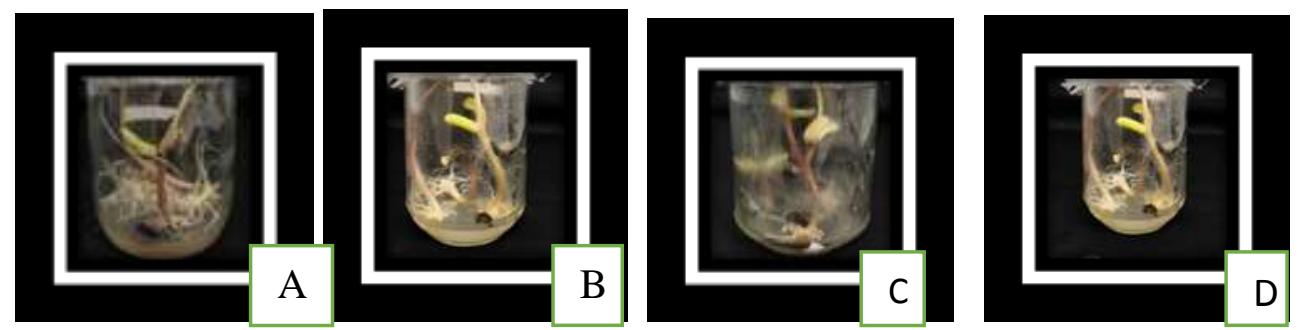

Gambar 1. Pertumbuhan planlet a. Pertumbuhan planlet $0 \%$, b. Pertumbuhan planlet $0,5 \%$, c. Pertumbuhan planlet $0,10 \%$, d. Pertumbuhan planlet $0,25 \%$

doi: http://dx.doi.org/10.23960/aec.v5.i1.2020.p34-41 Anal.Environ.Chem. 


\section{B. Kandungan Karbohidrat}

Analisis ini dilakukan untuk mengetahui kandungan karbohidrat yang terdapat pada planlet buncis yang telah ditanam di medium MS dan di induksi kalium dengan berbagai konsentrasi. Analisis kandungan karbohidrat yang dilakukan ini terdiri dari analisis kandungan karbohidrat total yang diukur dengan menggunakan spektrofotometer UV pada panjang gelombang $490 \mathrm{~nm}$.

\section{Kandungan Karbohidrat}

Kandungan karbohidrat pada batang buncis yang di induksi kalium dan PEG 6000 dengan berbagai konsentrasi disajikan pada Tabel 2 .

Tabel 2. Rerata kandungan karbohidrat terlarut total pada batang buncis yang di induksi kalium dan PEG 6000 per konsentrasi pada pengamatan minggu ke-3 kultur in vitro.

\begin{tabular}{ccccc}
\hline PEG 6000 & \multicolumn{4}{c}{ Konsentrasi Kalium (\%) } \\
\cline { 2 - 5 } $\begin{array}{c}\text { Konsentrasi } \\
(\%)\end{array}$ & 0 & 0,5 & 0,15 & 0,25 \\
\hline 20 & $0,17 \pm 0,01$ & $0,19 \pm 0,22$ & $0,16 \pm 0,01$ & $1,10 \pm 0,02$ \\
\hline
\end{tabular}

Keterangan :

Karbohidrat $=\bar{Y} \pm S E$

$\bar{Y}=$ Rata-rata karbohidrat

$\mathrm{SE}=$ Standar error

Hasil analisis ragam pada taraf 5\% menunjukkan bahwa pemberian kalium ke dalam medium MS dengan PEG 6000 tidak berpengaruh nyata $(0,810>0,05)$ terhadap kandungan kabohidat total buncis. Hal ini menunjukkan bahwa pemberian kalim tidak memberikan pengaruh nyata dalam meningkatkan kandungan karbohidrat total, hal ini diduga karena konsentrasi kalium yang diberikan tidak sesuai. Berdasarkan hasil analisis menunjukkan bahwa penggunaan medium MS dengan penambahan PEG 6000 serta kalium yang sesuai dapat meningkatkan kandungan karbohidrat pada planlet buncis.

Pemberian kalium belum memberikan respon dalam meningkatkan kandungan, karbohidrat terlarut total. Hal ini terjadi karena kemungkinan planlet buncis belum mampu menstimulasi karbohidrat terlarut total dengan baik, terbukti dengan adanya kotiledon yang

doi: http://dx.doi.org/10.23960/aec.v5.i1.2020.p34-41

Anal.Environ.Chem. 
menempel pada planlet, ini menunjukkan bahwa planlet buncis belum maksimal dalam melakukan fotosintesis dan masih menggunakan cadangan makanan pada kotiledon dalam pertumbuhannya. Penurunan kandungan karbohidrat pada saat tanaman kekurangan air akan berkaitan dengan aktivitasnya dan menghambat pembentukan karohidrat (Song, 2011).

\section{KESIMPULAN}

Berdasarkan penelitian yang telah dilakukan dapat disimpulkan bahwa pemberian kalium pada persentase planlet yang hidup menunjukkan 100\% hidup, tetapi belum memberikan reaksi terhadap kandungan karbohidrat terlarut total.

\section{DAFTAR PUSTAKA}

Badan Pusat Statistik (BPS). 2017. Pendapatan Non Migas-Holtikultura 2011. Badan Pusat Statistik. Jakarta

Fauzy, E., Mansyur dan Husni, A. 2016. Pengaruh Media Murashige and Skoog (MS) dan Vitamin Terhadap Tekstur, Warna dan Berat Kalus Rumput Gajah (Pennisetum purpureum) CV. Hawaii Pasca Radiasi Sinar Gamma Pada Dosis Ld50 (In Vitro). Universitas Padjadjaran. Bandung. Halaman 1-17.

Kerepesi, I., dan G. Galiba. 2000. Osmotic and Salt Stress-Induced Alteration in Soluble Carbohydrate Content in Wheat Seedlings. Crop Science 40(2000): 482-487

Kurniasari, A.M., Adisyahputra, dan R. Rosman. 2010. Pengaruh Kekeringan pada Tanag Beragam NaCl Terhadap Pertumbuhan Tanaman Nilam. Bull. Littro 21 (1) : 3.

Liu, H.Y., J.Y. Li, Y. Zhao dan K.K. Huang. 2007. Influence of Drought Stress On Gas Exchance and Water Use Efficiency of Salix psammophilia Growing In Five Places. Ari. Zone. Hal $815-820$.

Mariska, I., dan E.G. Lestari. 2006. Seleksi In Vitro untuk Toleransi terhadap Faktor Abiotik pada Tanaman Padi dan Kedelai. Seminar Nasional Pemanfaatan Bioteknologi untuk Mengatasi Cekaman Abiotik Pada Tanaman:28-41.

doi: http://dx.doi.org/10.23960/aec.v5.i1.2020.p34-41

Anal.Environ.Chem. 
Nurcahyani E, Mutmainah NA, Farisi S, dan Agustrina R. 2019a. Analisis Kandungan Karbohidrat Terlarut Total Planlet Buncis (Phaseolus vulgaris L.) Menggunakan Metode Fenol-Sulfur Secara In Vitro.Analit 4 (1): 73-80.

Nurcahyani E, Sazilly MR, Farisi S, dan Agustrina R. 2019b. Efek Inokulasi Rhizoctonia solanii Terhadap Kandungan Karbohidrat Terlarut Total Planlet Kacang Panjang (Vigna unguiculata (L.) Walp.) Secara In Vitro. Analit 4 (1): 81-90.

Saparinto, C. 2013. Grow Your Own Vegetables - Panduan Praktis Menanam 14 Sayuran Konsumsi Populer di Pekarangan. Lily Publisher. Yogyakarta.

Song, N. A. dan Banyo, Y. 2011. Konsentrasi Klorofil Daun Sebagai Indikator Kekurangan Air Pada Tanaman. Jurnal Ilmiah Sains. 11(2): 171.

Suriatana. 1987. Pupuk dan Pemupukan. Mediatama Sarana Perkasa. Jakarta.

Witham, Gille, K. A., Hamilton, J.K., Rebers PA dan Smith, F. 1993. Colometri method for Determination of Sugars and Related Subtance. Anal. Biochemistry Vol 143.

doi: http://dx.doi.org/10.23960/aec.v5.i1.2020.p34-41 